\title{
PEMANFAATAN LIMBAH SAYURAN UNTUK PELET PAKAN IKAN NILA (OREOCHROMIS NILOTICUS)
}

Siti Fanisya Afifah, Rachmaniyah*, Khambali

Jurusan Kesehatan Lingkungan Poltekkes Kemenkes Surabaya

*Email korespondensi: rachmaniyah.keslingsby@gmail.com

\begin{abstract}
ABSTRAK
Limbah sayuran seringkali dibuang ke lingkungan sehingga dapat membahayakan lingkungan dan mengganggu kesehatan. Pemilihan bahan baku limbah sayuran dapat dimanfaatkan menjadi pakan ikan yang berpotensi untuk mengurangi pencemaran lingkungan. Tujuan penelitian adalah mengetahui manfaat limbah sayuran untuk pelet pakan ikan nila (Oreochromis niloticus)dengan beberapa perlakuan limbah sayuran yang berbeda dan mengetahui kandungan zat gizi protein limbah sayuran.

Penelitian ini bersifat deskriptif menggunakan pendekatan Posttest Only Control Group Design dengan 4 perlakuan yaitu limbah sayuran (kontrol), pelet pakan ikan limbah sayuran $20 \%$, pelet pakan ikan limbah sayuran $30 \%$ dan pelet pakan ikan limbah sayuran $40 \%$. Pengukuran dari setiap perlakuan untuk mengetahui kandungan zat gizi protein.

Hasil penelitian diperoleh kandungan zat gizi protein limbah sayuran kubis dan kangkung (kontrol) yaitu sebesar $1,5185 \%$, pelet pakan ikan dengan limbah sayuran $20 \%$ sebesar 5,216\%, pelet pakan ikan dengan limbah sayuran $30 \%$ sebesar 3,981\% dan pelet pakan ikan dengan limbah sayuran $40 \%$ sebesar $3,678 \%$. Kualitas pelet pakan ikan belum memenuhi zat gizi protein yang sesuai dengan SNI 01-7242-2006 tentang Pembuatan Pakan Buatan Untuk Ikan Nila dalam proses pembesaran yaitu nilai protein minimal $25 \%$.

Disimpulkan bahwa pelet pakan ikan dari limbah sayuran kubis dan kangkung memiliki kandungan protein rendah. Disarankan perlu adanya penambahan bahan baku yang memiliki kandungan protein tinggi seperti limbah tulang ikan, limbah udang, limbah ampas tahu dan limbah bulu ayam, sehingga dapat menghasilkan pelet pakan ikan yang berkualitas baik untuk proses pembesaran ikan nila (Oreochromis nilocticus) yang mencapai kandungan protein yaitu minimal 25\% sesuai dengan SNI 01-7242-2006.
\end{abstract}

Kata kunci: Limbah Sayuran, Pelet Pakan Ikan Nila

\section{PENDAHULUAN}

Pakan ikan terdapat dua macam yaitu pakan ikan alami dan pakan ikan buatan. Pakan ikan buatan adalah pakan ikan yang berasal dari pengolahan beberapa bahan pakan yang memiliki dan memenuhi aspek kandungan nutrisi maupun kuantitas. Pelet ikan adalah salah satu bentuk pakan ikan yang sering digunakan dan yang paling banyak dijumpai di pasaran.

Pelet ikan adalah makanan buatan untuk ikan yang dibuat dari berbagai macam bahan yang digunakan dengan dicampur, dijadikan adonan dan kemudian dicetak menjadi batangan atau bulatan kecil-kecil. Bentuk pelet ikan tidak berupa tepung, butiran dan tidak berupa larutan (Setyono, 2012). Pelet ikan yang diperlukan oleh ikan adalah pelet ikan yang berkualitas baik yang mengandung protein, lemak, karbohidrat, vitamin dan mineral. Ikan membutuhkan makanan dengan kadar kandungan nutrisi protein sebesar (20-60\%), lemak (4-18\%), karbohidrat $(20-30 \%)$, vitamin dan mineral berkisar antara 2-5\% (Devani dkk, 2015).

Menurut penelitian Achadri et al (2018) dalam penelitiannya yang berjudul "Pemanfaatan Limbah Organik dari Rumah Makan Sebagai Alternatif Pakan Ternak Ikan Budidaya" mengemukakan bahwa limbah rumah makan yang dihasilkan adalah sisa sayuran, sisa buah-buahan dan sisa makanan rumah makan. Menurut Saputo (2016) bahwa sampah organik merupakan sampah yang mudah 
membusuk dan mencemari lingkungan. Berdasarkan studi pendahuluan yang dilakukan pada tanggal 26 November 2019 di Desa Tambak Kalisogo Kecamatan Jabon Kabupaten Sidoarjo terdapat 6 Lesehan Kolam Pancing yang menghasilkan limbah sayuran kubis dan kangkung dari limbah dapur. Setiap lesehan kolam pancing berat limbah sayuran kubis yang dihasilkan sekitar 2 $\mathrm{kg}$, limbah sayuran kangkung yang dihasilkan sebesar $1 \mathrm{~kg}$ dan total limbah sayuran yaitu sekitar $3 \mathrm{~kg}$ dalam satu hari yang tidak dilakukan pengolahan dan pemanfaatan.

Berdasarkan studi pendahuluan yang sudah dijelaskan diatas, sehingga peneliti dapat memecahkan masalah tersebut melalui penelitian tentang "Pemanfaatan Limbah Sayuran Untuk Pelet Pakan Ikan Nila (Oreochromis niloticus)". Tujuan dari penelitian ini adalah menganalisis manfaat limbah sayuran untuk pelet pakan ikan nila (Oreochromis niloticus), dengan mengukur berat limbah sayuran kubis dan kangkung.

\section{METODE PENELITIAN}

Jenis penelitian yang digunakan adalah true experiment dengan rancangan Posttest Only Control Group Design. Rancangan penelitian ini dapat membandingkan hasil dari kelompok kontrol dan kelompok eksperimen.

Variabel penelitian berupa dosis limbah sayuran sebagai campuran pelet pakan ikan yang mempengaruhi kandungan zat gizi protein. Sampel berupa limbah sayuran kubis dan kangkung. Penelitian ini menggunakan 4 kelompok yakni 3 kelompok perlakuan dan 1 kelompok kontrol.

Pelet pakan ikan dalam penelitian ini ada 3 perlakuan yaitu perlakuan 1 yaitu pembuatan pelet ikan dari $20 \%$ limbah sayuran $(10 \%$ kubis atau $100 \mathrm{~g}+10 \%$ atau $100 \mathrm{~g}$ kangkung) dengan bahan campuran (tepung kanji $37 \%$ atau $370 \mathrm{~g}$, dedak halus $37 \%$ atau $370 \mathrm{~g}$, tepung ikan $5,5 \%$ atau $55 \mathrm{~g}$, vitamin mix 0,5\% atau $5 \mathrm{~g}$ dan air secukupnya. Perlakuan 2 yaitu pembuatan pelet ikan dari 30\% limbah sayuran (15\% kubis atau $150 \mathrm{~g}+$ $15 \%$ atau $150 \mathrm{~g}$ kangkung) dengan bahan campuran (tepung kanji 32\% atau $320 \mathrm{~g}$, dedak halus $32 \%$ atau $320 \mathrm{~g}$, tepung ikan $5,5 \%$ atau $55 \mathrm{~g}$, vitamin mix $0,5 \%$ atau $5 \mathrm{~g}$ dan air secukupnya.

Perlakuan 3 yaitu pembuatan pelet ikan dari $40 \%$ limbah sayuran $(20 \%$ kubis atau $200 \mathrm{~g}+20 \%$ atau $200 \mathrm{~g}$ kangkung) dengan bahan campuran (tepung kanji $27 \%$ atau $270 \mathrm{~g}$, dedak halus $27 \%$ atau $270 \mathrm{~g}$, tepung ikan $5,5 \%$ atau $55 \mathrm{~g}$, vitamin mix 0,5\% atau $5 \mathrm{~g}$ dan air secukupnya. Selanjutnya Dari beberapa perlakuan tersebut, maka dilakukan pengujian laboratorium untuk mengetahui kandungan zat gizi protein pelet pakan ikan.

\section{HASIL DAN PEMBAHASAN}

Kandungan protein, karbohidrat, mineral dan vitamin dapat bermanfaat dijadikan sebagai pakan buatan ikan nila (Oreochromis niloticus). Hasil pengukuran menunjukkan bahwa hasil uji laboratorium kandungan zat gizi protein limbah sayuran kubis dan kangkung menghasilkan rata rata sebesar $1,5185 \%$. Rata rata kandungan zat gizi protein tertinggi terdapat pada perlakuan P1 untuk 20\% limbah sayuran memperoleh hasil sebesar 5,216\%, sedangkan kandungan zat gizi protein terendah diperoleh pada perlakuan P3 untuk $40 \%$ limbah sayuran dengan ratarata sebesar $3,678 \%$. Perlakuan P2 untuk $30 \%$ limbah sayuran menghasilkan ratarata kandungan zat gizi protein sebesar $3,981 \%$.

\section{Kandungan zat gizi protein pada limbah sayuran kubis dan kangkung}

Berdasarkan jurnal penelitian Fitriyani et.al (2014) dengan judul penelitian "Pemanfaatan Limbah TulangTulang Ikan Menjadi Pelet Pakan Ikan Untuk Menciptakan Kawasan Zero Waste di Pantai Baru Pandansimo Kabupaten Bantul" mengemukakan bahwa hasil uji analisis kandungan protein nutrisi limbah tulang ikan dan limbah udang cukup tinggi dengan nilai protein limbah tulang ikan sebesar $29,88 \%$ dan limbah udang sebesar 35,44\%.

Berdasarkan jurnal penelitian Anggraeni dkk, (2016) mengatakan bahwa hasil uji analisis kandungan 
protein nutrisi limbah ampas tahu cukup tinggi yaitu sebesar 25,96\%. Menurut Sahwan, M. F. (2001) mengatakan bahwa kandungan protein nutrisi limbah bulu ayam/ unggas cukup tinggi yaitu sebesar $82-91 \%$. Maka limbah tulang ikan, limbah udang, limbah ampas tahu dan limbah bulu ayam/unggas dapat dijadikan sebagai bahan tambahan untuk dijadikan sebagai pelet pakan ikan. Sehingga hal ini dapat diaplikasikan terhadap penelitian ini yaitu dengan penambahan bahan baku dari limbah tulang ikan yang memeliki kandungan protein sebesar $29,88 \%$, limbah udang $(35,44 \%)$, limbah ampas tahu $(25,96 \%)$ dan limbah bulu ayam/ unggas (82-91\%) dapat mempengaruhi kandungan protein yang cukup tinggi dan sesuai standar SNI 01-7242-2006 dalam upaya pembuatan pelet pakan yang mengandung protein minimal $25 \%$ untuk ikan nila.

\section{Kandungan zat gizi protein pada pelet pakan ikan dengan variasi limbah sayuran $20 \%, 30 \%$ dan $40 \%$}

Kandungan zat gizi protein pada pelet pakan ikan dengan ketiga variasi limbah sayuran menunjukkan belum memenuhi SNI 01-7242-2006 tentang Pembuatan Pakan Buatan untuk Ikan Nila (Oreochromis spp) pada Budidaya Intensif dengan hasil kandungan zat gizi protein pada ikan nila untuk proses pembesaranminimal 25\%. Menurut penelitian Fitriyani dkk. (2014) mengemukakan hasil uji kualitas pelet pakan ikan dari limbah tulang ikan dan limbah udang menghasilkan analisa kandungan zat gizi protein pada pelet $\mathrm{P} 1$ sebesar $26,52 \%$, P2 kandungan zat gizi protein sebesar $32,56 \%$, P3 kandungan zat gizi protein sebesar $35,57 \%$, P4 kandunganzat gizi protein sebesar $34,34 \%$ dan P5 kandungan zat gizi protein sebesar $34,78 \%$.

Berdasarkan penelitian Anggraeni dkk, (2016) mengemukakan hasil uji kualitas pelet pakan ikan dari limbah ampas tahu menghasilkan analisa kandungan zat gizi protein pada pelet ikan perlakuan AT1 (ampas tahu $80 \%+$ kepala ikan 20\%) sebesar 42,01\%, perlakuan AT2 (ampas tahu $80 \%+$ kepala udang 20\%) sebesar 43,05\%. Kandungan protein yang cukup baik dan tinggi juga dari penambahan limbah ikan dan udang yang ditambah dengan kandungan zat gizi protein yang cukup tinggi dari limbah ampas tahu.

Berdasarkan penelitian Suwarto, (2017) mengemukakan hasil uji analisis kandungan protein pelet dari campuran limbah bulu ayam dengan tiga model perlakuan U1 sebesar 35,57\%, U2 sebesar 35,04\% dan U3 sebesar 35,08\%. Sehingga limbah tulang ikan, limbah udang, limbah ampas tahu dan limbah bulu ayam dapat dijadikan sebagai bahan tambahan untuk dijadikan sebagai pelet pakan ikan. Sehingga memberikan pengaruh terhadap kandungan zat gizi protein yang tinggi agar dapat mencapai kandungan protein sesuai dengan standar SNI 01-7242-2006.

Kelemahan dalam penelitian ini yaitu dari kandungan zat gizi protein limbah sayuran kubis dan kangkung yang rendah. Sehingga rekomendasi yang dapat diberikan dalam penelitian yaitu dengan penambahan dari limbah tulang ikan, limbah udang, limbah ampas tahu maupun limbah bulu ayamagar dapat memberikan pengaruh terhadap kandungan zat gizi protein yang tinggi hingga mencapai kandungan protein sesuai dengan standar SNI 01-72422006.

\section{Kualitas pelet pakan ikan dengan SNI 01-7242-2006 tentang Pembuatan Pakan Buatan Untuk Ikan Nila}

Analisa kandungan zat gizi protein menyatakan ketiga perlakuan pelet pakan ikan dengan variasi limbah sayuran $20 \%$ memiliki nilai protein sebesar 5,216\%, pelet pakan ikan dengan variasi limbah sayuran $30 \%$ mengandung protein sebesar 3,981\% dan pelet pakan ikan untuk variasi limbah sayuran $40 \%$ menghasilkan nilai protein sebesar 3,678\%. Sehingga hasil analisa laboratorium untuk ketiga perlakuan pelet pakan ikan tidak memenuhi kualitas kandungan zat gizi protein yang sesuai dengan SNI 01-7242-2006 tentang Pembuatan Pakan Buatan Untuk Ikan Nila dalam persyaratan proses 
pembesaran yang terkandung nilai protein minimal $25 \%$.

Hal ini menunjukkan bahwa kandungan zat gizi protein pada ketiga variasi pelet pakan ikan seiring meningkatnya jumlah limbah sayuran yang ditambahkan dari perlakuan P1 sampai P3 tidak ada yang memenuhi kualitas mengenai kandungan zat gizi protein. Sehingga dari ketiga variasi limbah sayuran pelet pakan ikan kurang baik untuk makanan ikan karena kandungan zat gizi protein rendah.

Menurut Akimaya et.al dalam Rachmawati dkk,(2013) bahwa kurangnya kandungan zat gizi protein pada pakan dapat menyebabkan terhambatnya pertumbuhan, sehingga dapat diikuti kehilangan bobot tubuh yang digunakan untuk pemakaian protein dari jaringan tubuh diperuntukan untuk memelihara funsi vital. Sedangkan menurut NRC 1983 dalam Rachmawati dkk,(2013) tingginya kandungan zat gizi protein dalam pakan tidak semua akan menyebabkan peningkatan pertumbuhan.

Menurut penelitian Kordi,(2007) dalam Rahayu et.al(2016) pakan yang kekurangan kandungan zat gizi protein dapat berpengaruh negatif terhadap konsumsi dari pakan, sedangkan untuk pemberian kandungan zat gizi protein yang cukup maka akan mempengaruhi pertumbuhan ikan.Kelemahan penelitian ini yaitu bahwa kandungan zat gizi protein pelet pakan ikan dengan penambahan beberapa variasi limbah sayuran memiliki kandungan gizi protein yang rendah. Evaluasi dari hasil penelitian bahwa pembuatan pelet pakan ikan harus lebih memperhatikan dalam pemilihan bahan baku yang memiliki zat gizi protein yang cukup tinggi agar dapat memberikan kualitas pelet pakan ikan yang baik sesuai dengan Standar Nasional Indonesia 01-7242-2006 bahwa untuk pakan ikan nila dalam proses pembesaran nilai protein yang terkandung minimal $25 \%$.

\section{KESIMPULAN}

Berdasarkan hasil penelitian yang dilakukan diatas sehingga dapat disimpulkan Kandungan zat gizi protein pada limbah sayuran kubis dan kangkung mengandung nilairata-rata sebesar $1,5185 \%$. Ketiga variasi pelet pakan ikan dengan limbah sayuran 20\% (P1) memiliki nilai rata-rata protein sebesar $5,216 \%$, pelet pakan ikan untuk limbah sayuran 30\% (P2) menghasilkan nilai rata-rata protein sebesar 3,981\% dan untuk pelet pakan ikan dengan limbah sayuran $40 \%$ mengandung nilai rata-rata protein sebesar 3,678\%.

\section{SARAN}

Limbah sayuran dapat dijadikan pakan buatan dalam bentuk pelet dengan penambahan bahan baku yang memiliki kandungan protein yang tinggi seperti limbah tulang ikan, limbah udang, limbah ampas tahu dan limbah bulu ayam agar mencapai standar yang sudah ditetapkan.

\section{DAFTAR PUSTAKA}

Achadri, Y., Tyasari, F. G., Dughita, P. A. 2018. Pemanfaatan Limbah Organik dari Rumah Makan Sebagai Alternatif Pakan Ternak Ikan Budidaya. Agronomika Vol. 13 No. 1.

Anggraeni, N.M., Abdulgani, N. 2013. Pengaruh Pemberian Pakan Alami dan PakanBuatan Terhadap Pertumbuhan Ikan Betutu (oxyeleotris marmorata) pada SkalaLaboratorium. Jurnal Sains dan Seni Pomits Vol. 2, No. 1.

Anggraeni, D. N., Rahmiati. 2016. Pemanfaatan Ampas Tahu Sebagai Pakan Ikan Lele (Clarias batrachus) Organik.

Devani, V., Basriati, S. 2015. Optimasi Kandungan Nutrisi Pakan Ikan Buatan Dengan Menggunakan Multi Objective (Goal) Programming Model.Jurnal Sains, Teknologi Dan Industri Vol. 12 No. 2.

Kordi, M. Ghufran H. 2007. Meramu Pakan untuk Ikan Karnovora. Semarang: CV. Aneka Ilmu.

Rachmawati, D., Samidjan, I. 2013. Efektivitas Subtitusi Tepung Ikan dengan Tepung Maggot dalam Pakan Buatan Terhadap Pertumbuhan dan Kelulushidupan 


$\begin{array}{llll}\text { Ikan Patin. Jurnal Saintek } & \begin{array}{l}\text { Budidaya Intensif. Badan } \\ \text { Perikanan. }\end{array}\end{array}$

Sahwan, M. F. 2001. Pakan Ikan dan Udang. Jakarta: Penebar Swadaya.

Saputo, W. 2016. Pengelolaan Limbah atau Sampah Organik.

Setyono, B. 2012. Pembuatan Pakan Buatan. Malang : Unit Pengelola Air Tawar.

Standar Nasional Indonesia. 2006. SNI

01-7242-2006. Pembuatan Pakan Buatan untuk Ikan Nila pada
Suwarto. 2017. Pemanfaatan Limbah Bulu Ayam Potong Sebagai Pelet Pakan Lele Untuk Menekan Biaya Produksi Beternak Lele. Thegorbalsla. https://thegorbalsla.com/ikan-nila/ (diakses pada tanggal 6 Januari 2020 jam 20:07) Undang-Undang Republik Indonesia Nomor 18 Tahun 2008. Pengelolaan Sampah. Jakarta: Sekretariat Negara. 